\title{
Article \\ Screening for Melanoma and Other Skin Cancer Shows a Higher Early Melanoma Incidence: Social Educational Program "Life Fear-Free"
}

\author{
Lev Demidov ${ }^{1}$, Igor Samoylenko ${ }^{1, *(\mathbb{D})}$, Nina Vand ${ }^{2}$, Igor Utyashev ${ }^{1}\left(\mathbb{D}\right.$, Irina Shubina ${ }^{1, *(\mathbb{C})}$ and Igor Sinelnikov ${ }^{2}$ \\ 1 FSBI N.N. Blokhin National Medical Research Center of Oncology, Ministry of Health of Russia, \\ Moscow 115548, Russia; demidov.lev@gmail.com (L.D.); dr.utyashev@gmail.com (I.U.) \\ 2 Russian Melanoma Professional Association (Melanoma.PRO), Moscow 119192, Russia; \\ nina.s.vand@gmail.com (N.V.); sinelnikov.igor@gmail.com (I.S.) \\ * Correspondence: igor.samoylenko@gmail.com (I.S.); irinashubina@mail.ru (I.S.)
}

check for updates

Citation: Demidov, L.; Samoylenko, I.; Vand, N.; Utyashev, I.; Shubina, I.; Sinelnikov, I. Screening for Melanoma and Other Skin Cancer Shows a Higher Early Melanoma Incidence: Social Educational Program "Life Fear-Free". Dermatopathology 2021, 8, 54-68. https://doi.org/10.3390/ dermatopathology 8010011

Academic Editor: Gürkan Kaya

Received: 12 February 2021

Accepted: 12 March 2021

Published: 15 March 2021

Publisher's Note: MDPI stays neutral with regard to jurisdictional claims in published maps and institutional affiliations.

Copyright: (c) 2021 by the authors. Licensee MDPI, Basel, Switzerland. This article is an open access article distributed under the terms and conditions of the Creative Commons Attribution (CC BY) license (https:// creativecommons.org/licenses/by/ $4.0 /)$.

\begin{abstract}
Background: The screening program Life Fear-Free (LFF) aimed at early diagnosis of cutaneous melanoma (CM) was introduced in Samara, Chelyabinsk, Yekaterinburg, and Krasnodar (Russia) in 2019. Objectives: To analyze the impact of the program on early CM and non-melanoma skin cancer (NMSC) detection. Methods: According to the social educational campaign, people were informed about $\mathrm{CM}$ risk factors and symptoms and were invited for skin examination. The program planned to involve 3200 participants in total. Participants with suspicious lesions were invited for excisional biopsy. Results: 3143 participants, including 75.4\% women, were examined for skin lesions. The average age of the participants was 43.7 years. Mostly skin phototypes II and III were registered (48.2\% and $41.0 \%$, respectively); 3 patients had CM, 15 had basal cell carcinoma, and 1 had Bowen's disease, which were confirmed histologically. All detected melanomas had Breslow's thickness of $1 \mathrm{~mm}$. Conclusion: The participants showed high interest in early skin cancer detection programs. The incidence rate of CM and NMSCs among the program participants was higher than in general public. The early disease grade was proven for the detected CMs and NMSCs. The study has shown that it is important to continue such programs.
\end{abstract}

Keywords: cutaneous melanoma; melanoma screening; skin cancers; social and educational program

\section{Introduction}

According to World Health Organization statistical data (WHO, 2018), cancer is one of the major causes of death worldwide, with skin cancers holding the fifth rank, and cutaneous melanoma (CM) causing most deaths of skin cancers [1]. Timely referral to the doctor helps early detection and removal of thinner CMs $(<1 \mathrm{~mm})$, which leads to positive outcomes for the patients [2]. Thus, early CM diagnosis is an essential target for national healthcare.

An earlier epidemiological study showed that the average melanoma thickness accounted for $>4 \mathrm{~mm}$ at the first medical examination in Russia [3]. A study in 2018 revealed several problems, such as: people were almost unaware of the disease; procedures for excisional biopsy were too complicated; insufficient special training of primary care personnel (in 2018, CM was detected in $31.9 \%$ of patients, comparable with $45.5 \%$ of patients with detected skin cancer [1]). Pathological CM overdiagnosis or underdiagnosis have become a frequent problem worldwide including Russia [4]. Each of these factors ultimately affects the final data of the early detected melanomas and the mortality rate from CM.

The Melanoma Professional Association (MPA) supported by BIOCAD (Biotech company, Russia) designed a social educational program "Life Fear-Free" (LFF) for early CM detection. The major goal was to evaluate the impact of the LFF program on early CM and non-melanoma skin cancer (NMSC) detection. In addition, the participants' answers should 
provide the data for population awareness about skin melanoma, its risk factors, prevention, and early diagnosis. The program was implemented in four Russian cities in 2019.

\section{Materials and Methods}

\subsection{Program Participants}

The only inclusion criterion for the program participants was age limit-adults over 18. The cities of Samara, Chelyabinsk, Yekaterinburg, and Krasnodar, whose residents were involved in the Program, were chosen based on the CM incidence rate, population $>1$ million, and regional healthcare support. The LFF program enrolled 3143 participants. The number of female participants was significantly higher than male participants, including 2369 women $(75.4 \%)$ and 774 men (24.6\%). Such a proportion was almost the same in all studied regions. The average age accounted for 43.7 (95\% confidence interval (CI): 43.2-44.3) years. However, the age difference was registered as following: the average age of 44.7 (95\% CI: 43.6-45.7) and 45.1 (95\% CI: 44.2-45.9) in Samara and Chelyabinsk, respectively, was higher than that of Yekaterinburg, and Krasnodar, 41.6 (95\% CI: 40.4-42.8) and 42.1 (95\% CI: 40.6-43.6), respectively.

The analysis also included historical data received after program LFF completion.

\subsection{Analysis of Melanoma Awareness}

Prior to the start of the screening program, an information and communication campaign was carried out in the involved cities. The campaign lasted for 2-4 weeks and included:

- design and launch of information and educational "long-read" websites about melanoma and the importance of its early diagnosis;

- launch of advertising and informational videos on TV;

- launch of advertising and information programs on the radio;

- presentations of leading oncologists and/or dermatologists of the region on TV;

- announcement of the LFF program on the regional news channels and information websites;

- announcement of the LFF program in social networks;

- contextual advertising; and

- information in bloggers' posts.

At the first stage of the LFF program, a sociological study assessed participants' melanoma awareness and their willingness for self-monitoring their moles or visiting a medical unit for lesion monitoring. The survey involved 1600 respondents who answered by phone. The interviews were conducted in accordance with the stratified dual-frame random sample selection [5].

\subsection{Examinations}

The participants made an appointment with the doctor via special website or by phone. All participants gave their written informed consent for inclusion before they participated in the study. The study was conducted in accordance with the Declaration of Helsinki, and the program was approved by the Ethics Committee of the Federal State Budgetary Institution "N.N. Blokhin National Medical Research Center of Oncology" of the Ministry of Health of Russia (Program approval of 5.08. 2019).

Skin examinations were performed in a two-stage mode. In Samara and Yekaterinburg, dermatologists/venereologists completed the first-stage skin examination by a dermatoscope. In Chelyabinsk and Krasnodar, oncologists performed the first-stage skin examination with or without dermatoscopes. In case of a suspicious lesion, the participant went for the second-stage examination visiting an oncologist/oncodermatologist.

All participants filled in a questionnaire concerning CM risk factors. When the participant visited the medical unit, the doctor evaluated the skin phototype and the number of nevi, and reported of any suspicious lesion in a special card in the questionnaire. The doctor classified all skin lesions as following: (1) Suspicion of melanoma or skin cancer; (2) healthy, with a high risk of skin cancer OR benign lesions; or (3) healthy. No further consultation 
is required. The organization of the second-stage examination was similar to the first one and finally, the doctor decided whether a skin biopsy was required. The biopsy procedure was then organized in accordance with the local practice (Figure 1).

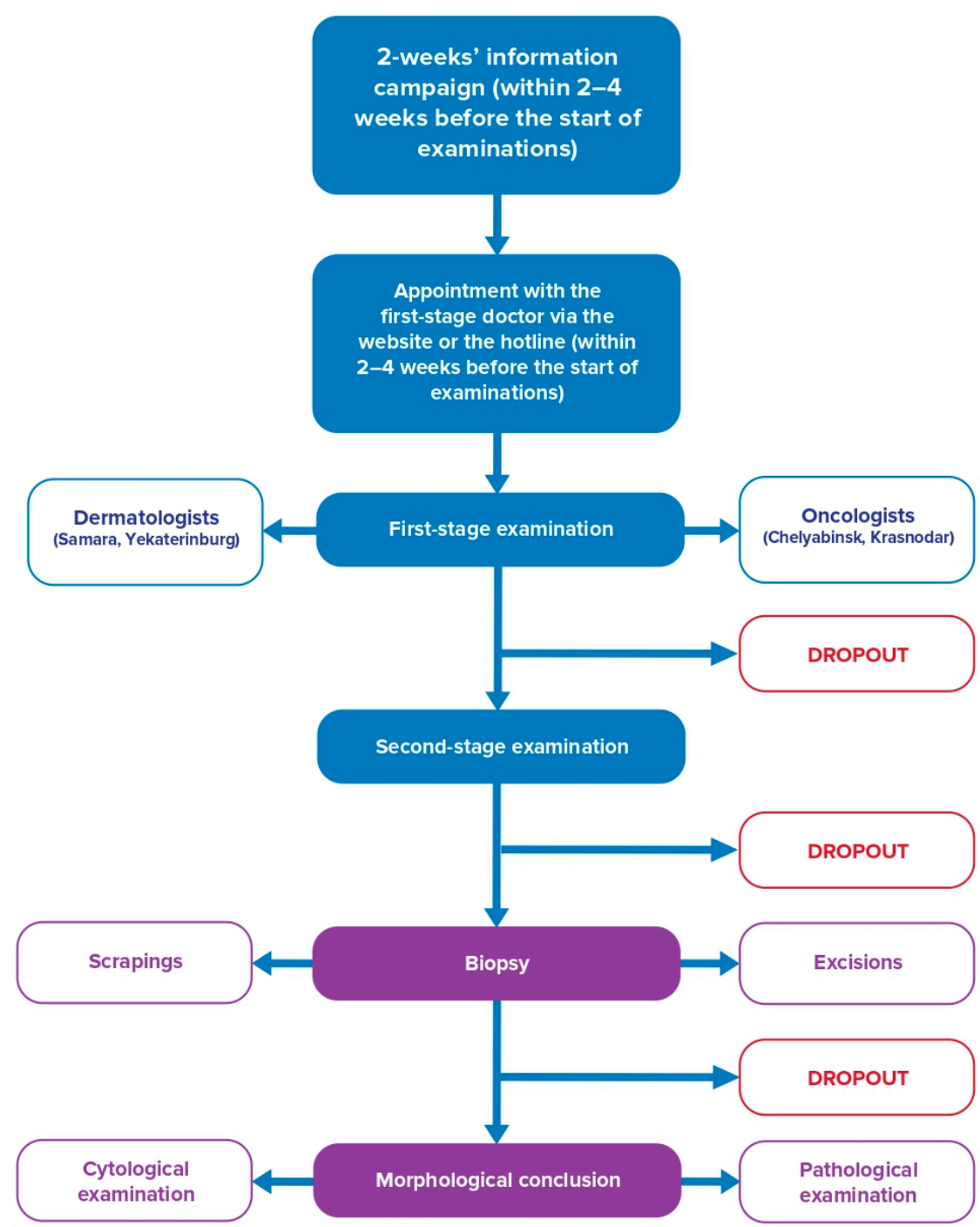

Figure 1. The flow chart of the study of the program "Life Fear-Free".

\subsection{Statistics}

According to the program, the number of participants should be 3200 across four regions ( 800 per city). The collected anonymized data were analyzed by descriptive statistics.

\section{Results}

\subsection{Awareness of the Population about Early Detection of Skin Cancer}

The survey results showed that a high percentage of respondents had incorrect understanding about melanoma and skin cancer, their risk factors, and treatment methods.

Approximately $57 \%$ of the respondents either never heard the word "melanoma" $(36 \%)$ or could not explain the meaning (21\%). However, only $25 \%$ (out of $43 \%$ of respondents who claimed they could explain the meaning of the term) were able to describe correctly the term melanoma as a "malignant skin lesion". Only $31 \%$ of respondents associated the development of melanoma with a sunburn, while $38 \%$ were convinced that melanoma resulted from a mole trauma. Approximately $52 \%$ of the respondents were sure that bleeding of the "mole" was the only reason why they should consult a doctor [5]. The LFF program included preparation and distribution of the information and educational materials among 
the participants. The materials consisted of posters and leaflets with patient-oriented pictures and texts, explaining melanoma and skin cancer features, what may cause them, how you should monitor your moles, and how to take medical examination [6]. The effect of distribution of these materials in terms of melanoma awareness has not been studied, yet.

\subsection{Organization of Skin Examination}

In total, 3143 participants from four regions of Russia took part in the LFF program from 15 October 2019 to 14 December 2019.

The study period in four regions varied according to the preferences of the regional medical organizations (Table 1).

Table 1. Organization of the social educational program "Life Fear-Free" aimed at the early detection of melanoma and skin cancers.

\begin{tabular}{|c|c|c|c|c|c|}
\hline & Samara & Chelyabinsk & Yekaterinburg & Krasnodar & Total \\
\hline $\begin{array}{l}\text { Information and } \\
\text { communication campaign } \\
\text { start date }\end{array}$ & 5 October 2019 & 8 October 2019 & 12 November 2019 & 26 November 2019 & - \\
\hline $\begin{array}{l}\text { Duration of the } \\
\text { information and } \\
\text { communication campaign } \\
\text { before the start of the } \\
\text { examinations (days) }\end{array}$ & 11 days & 18 days & 18 days & 18 days & - \\
\hline $\begin{array}{l}\text { Start and end dates for } \\
\text { examination appointment }\end{array}$ & 5-14 October 2019 & $\begin{array}{c}2 \text { October } \\
1-22 \text { October } 2019\end{array}$ & $\begin{array}{c}8 \text { October } \\
1-2 \text { December } 2019\end{array}$ & $\begin{array}{c}23 \text { November } \\
\text { 1_7 December } 2019\end{array}$ & - \\
\hline $\begin{array}{l}\text { Start date for first-stage } \\
\text { examinations }\end{array}$ & 15 October 2019 & 26 October 2019 & 3 December 2019 & 14 December 2019 & - \\
\hline $\begin{array}{l}\text { Duration of first-stage } \\
\text { examinations (days) }\end{array}$ & $\begin{array}{c}4 \text { days } \\
\text { (15-18 October) }\end{array}$ & $\begin{array}{c}2 \text { days } \\
(26-27 \text { October })\end{array}$ & $\begin{array}{c}5 \text { days } \\
\text { (3-7 December) }\end{array}$ & $\begin{array}{c}1 \text { day } \\
\text { (14 December) }\end{array}$ & 12 \\
\hline $\begin{array}{l}\text { Start date for second-stage } \\
\text { examinations }\end{array}$ & 16 October 2019 & 26 October 2019 & 7 December 2019 & 14 December 2019 & - \\
\hline $\begin{array}{l}\text { Duration of second-stage } \\
\text { examinations (days) }\end{array}$ & $\begin{array}{c}4 \text { days } \\
\text { (16-19 October) }\end{array}$ & $\begin{array}{c}2 \text { days } \\
\text { (26-27 October) }\end{array}$ & $\begin{array}{c}6 \text { days } \\
\text { (7 December, } \\
\text { 9-13 December) }\end{array}$ & $\begin{array}{c}1 \text { day } \\
\text { (14 December) }\end{array}$ & 13 \\
\hline
\end{tabular}

${ }^{1}$ The participants started making appointments before the information and communication campaign since the appointment option was open on the program website before the start of the information and communication campaign.

\subsection{Evaluation of Risk Factors for CM}

In general, the distribution of risk factors related to CM and NMSC development was similar in four regions. The paper presents the data of the total population involved in the study. On the whole, 2369 women $(75.4 \%)$ and 774 men $(24.6 \%)$ participated in the program.

At the first stage, mostly participants with Fitzpatrick skin phototype II and III ( $48.2 \%$ and $41.0 \%$, respectively) were enrolled in the study, while at the second stage the number of people with skin phototype I and II tended to rise. We observed a similar trend in the population with a large number of skin nevi, previous history of sunburns, and malignancies in their personal or family history (Figures 2-6). 
All participants
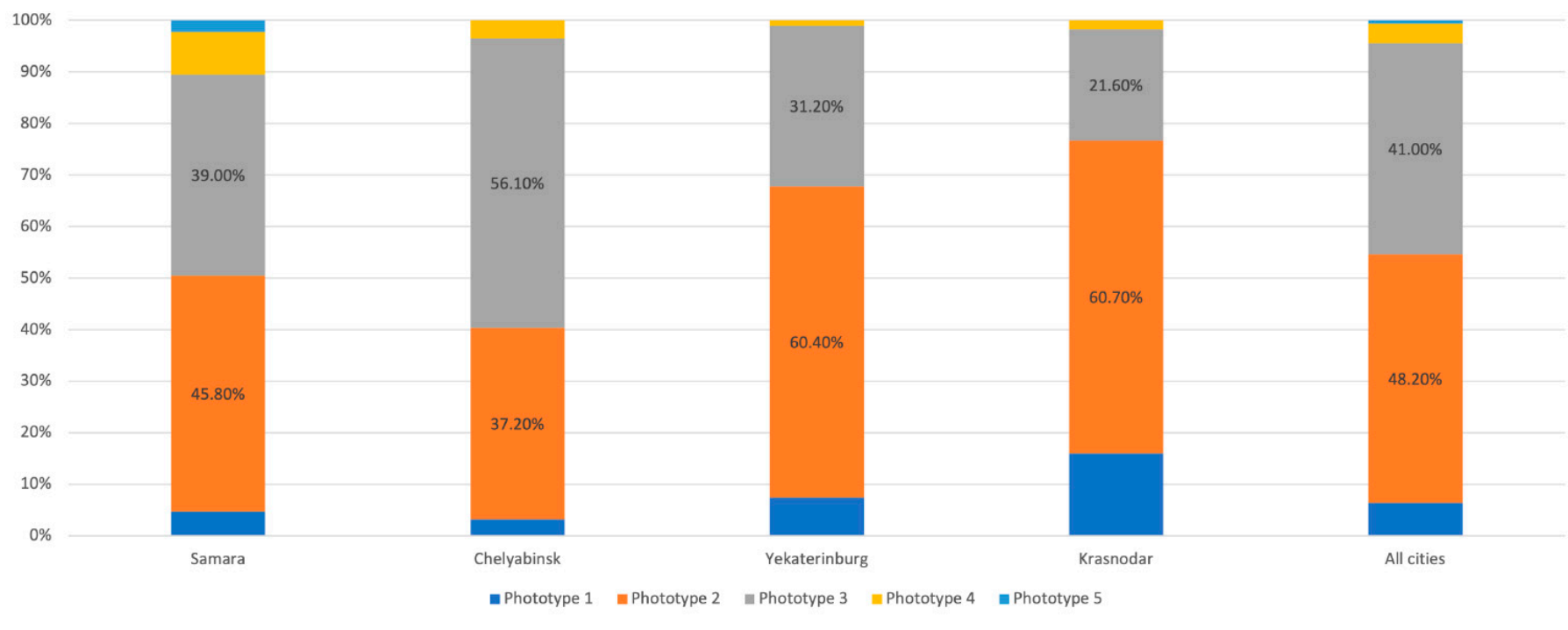

(A)

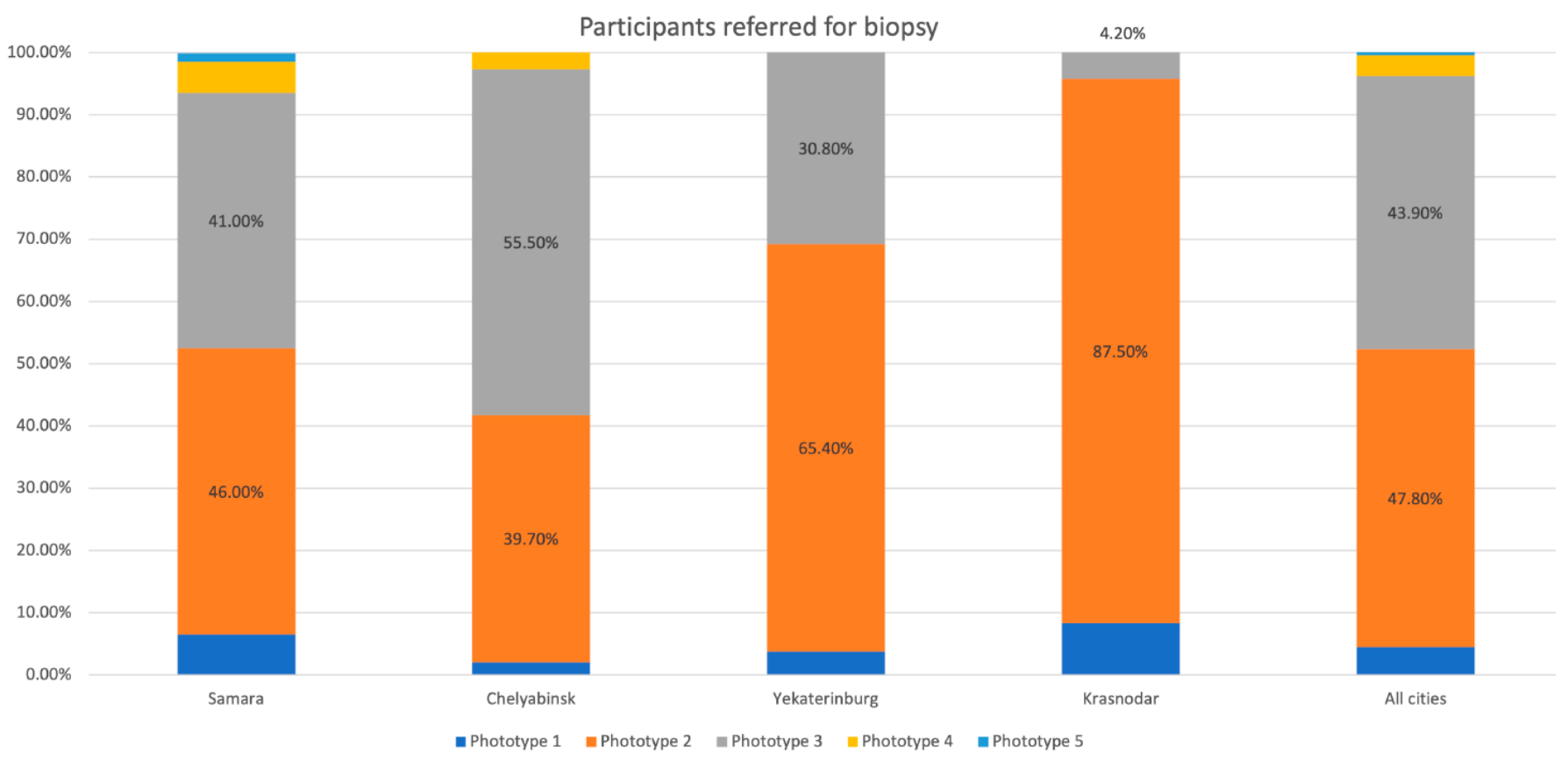

(B)

Figure 2. Distribution of the participants by skin phototype in the studied regions. (A) All participants. (B) Participants with suspected melanoma or other skin cancers. 


\section{All participants}

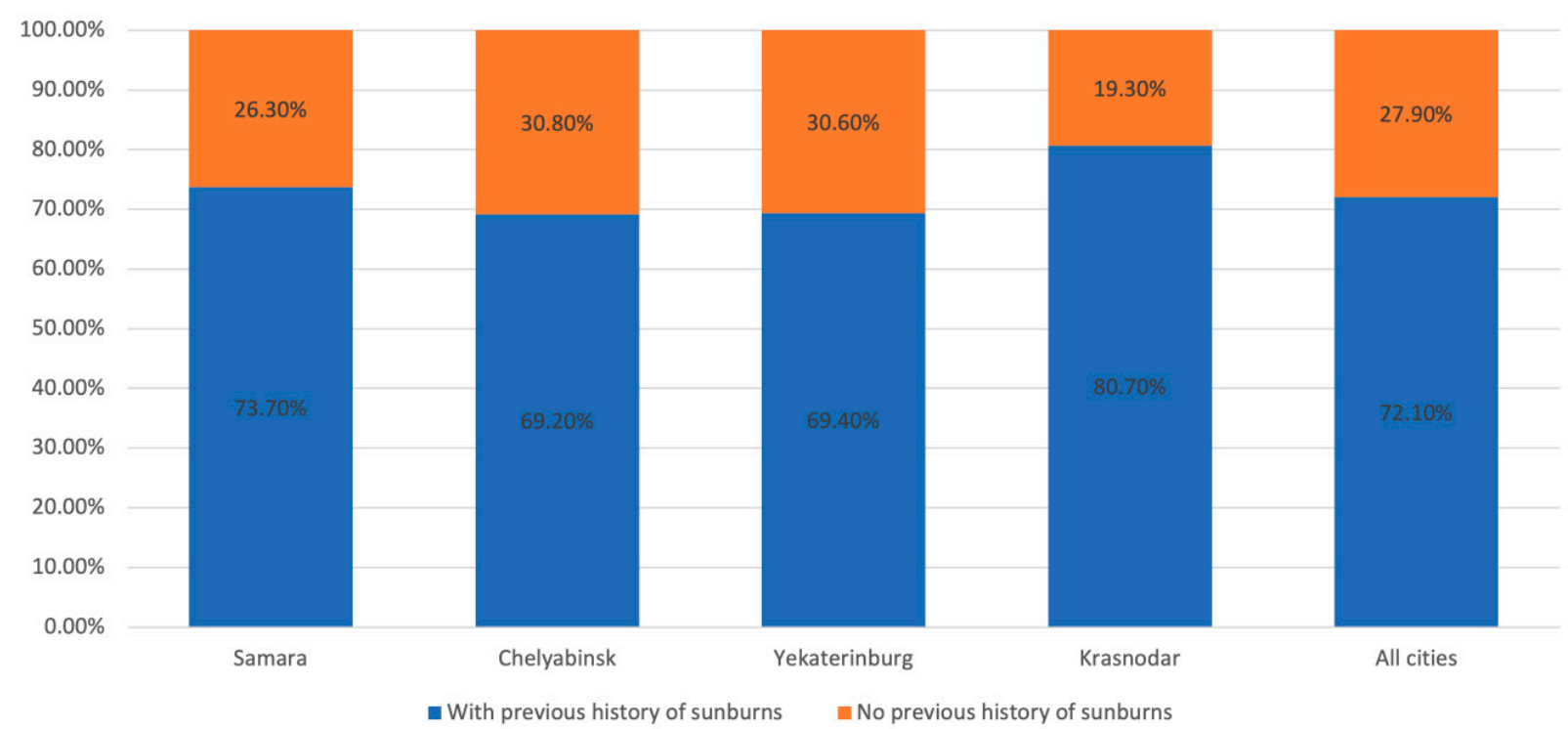

(A)

\section{Participants referred for biopsy}

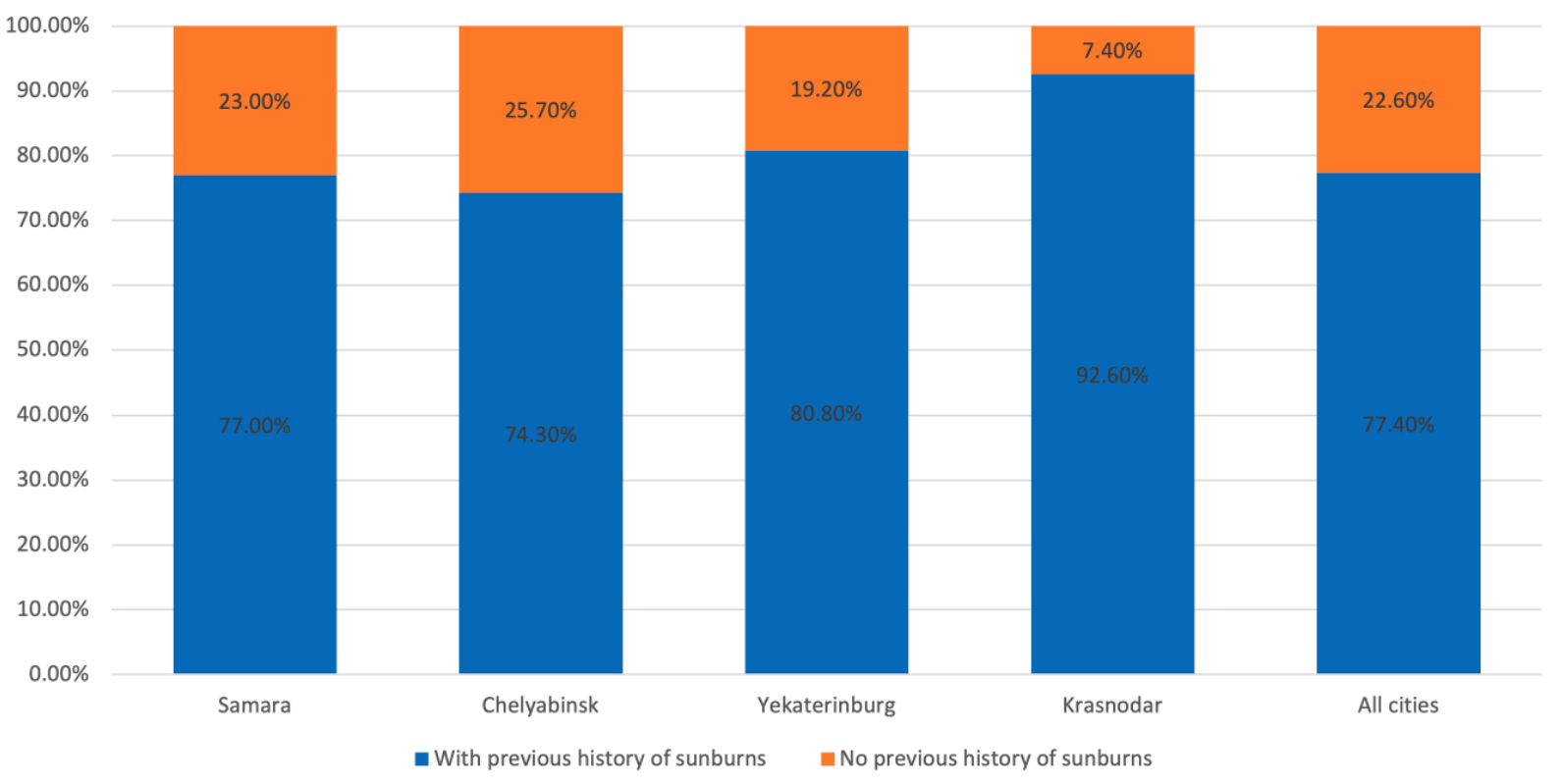

(B)

Figure 3. Distribution of the participants by previous sunburns in the studied regions. (A) All participants. (B) Participants with suspected melanoma or other skin cancers. 


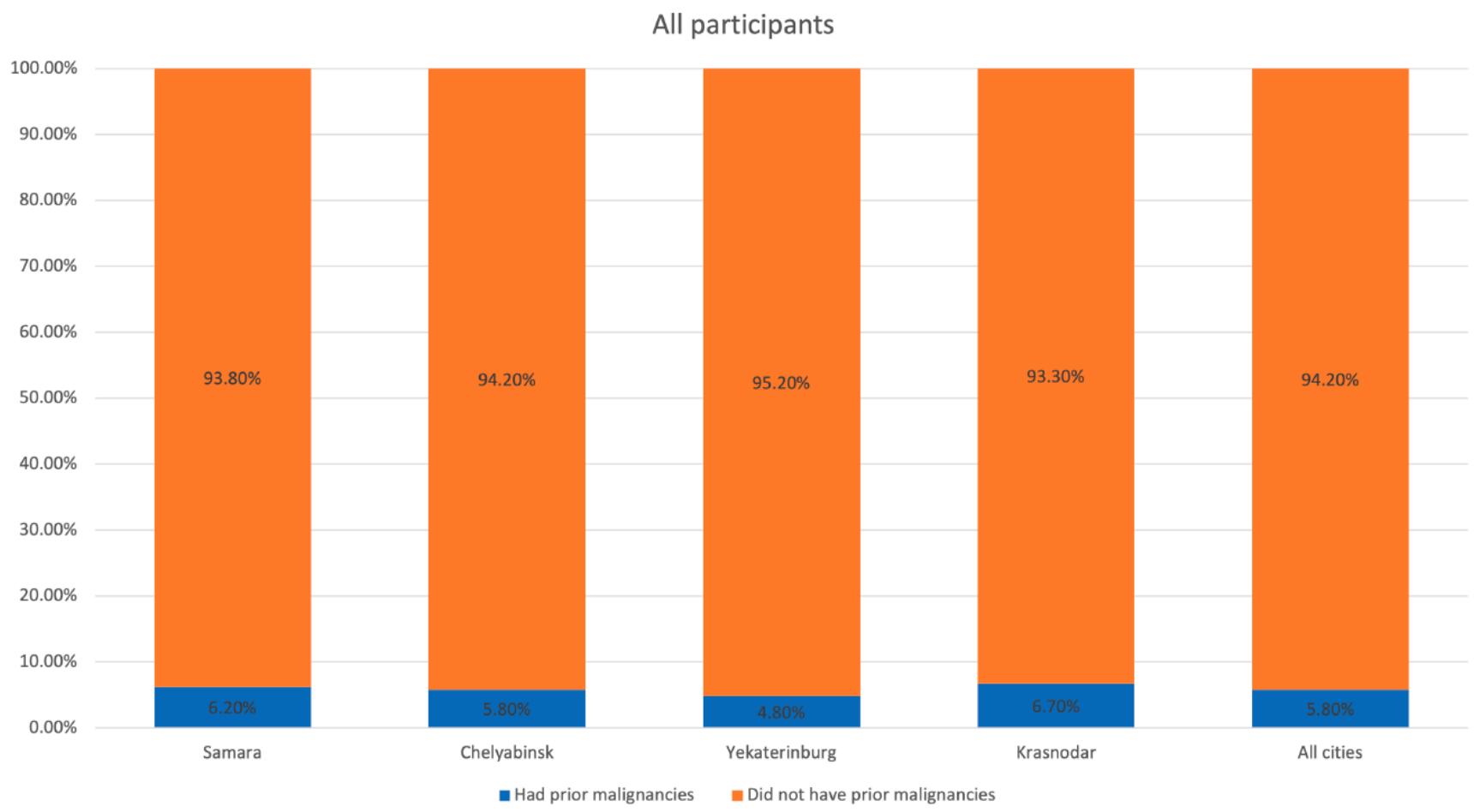

(A)

\section{Participants referred for biopsy}

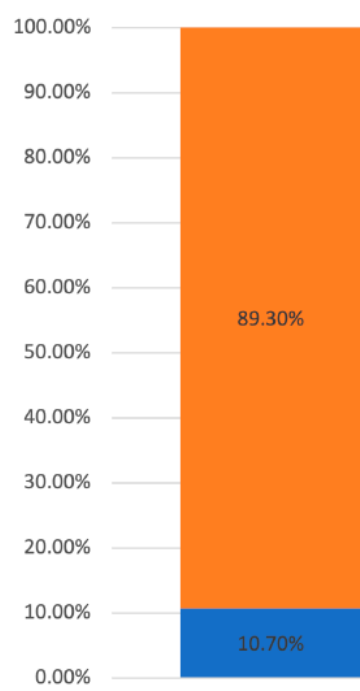

Samara
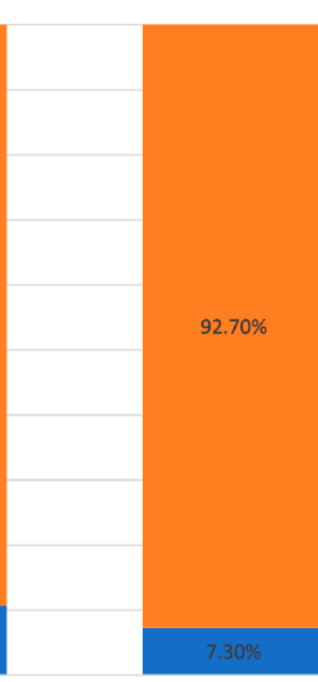

Chelyabinsk

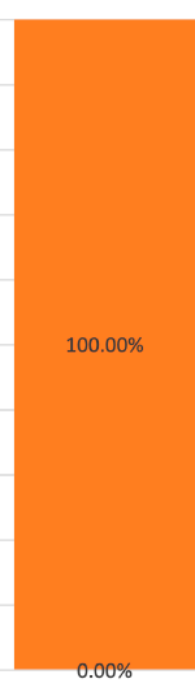

Yekaterinburg

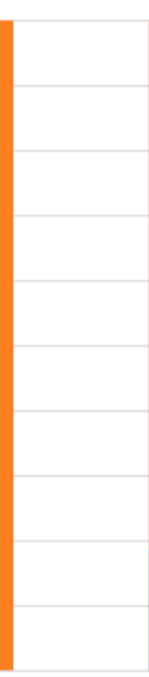

- Had prior malignancies

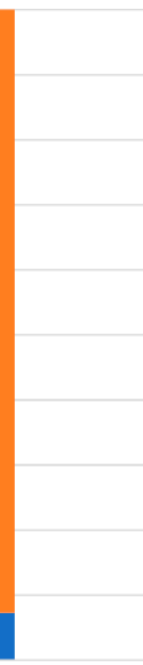

n Did not have prior malignancies

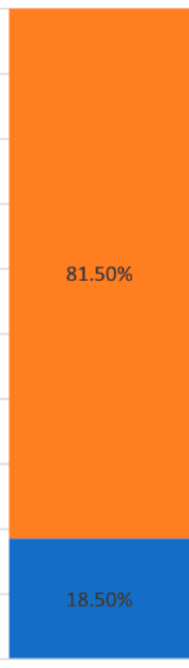

Krasnodar

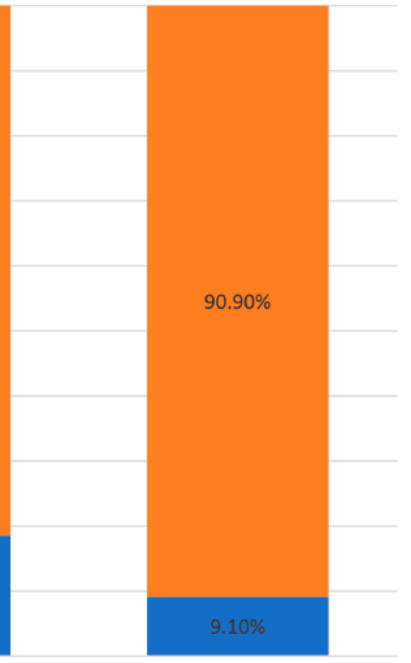

All cities

(B)

Figure 4. Distribution of the participants by the cancer in their personal history in the studied regions. (A) All participants. (B) Participants with suspected melanoma or other skin cancers. 


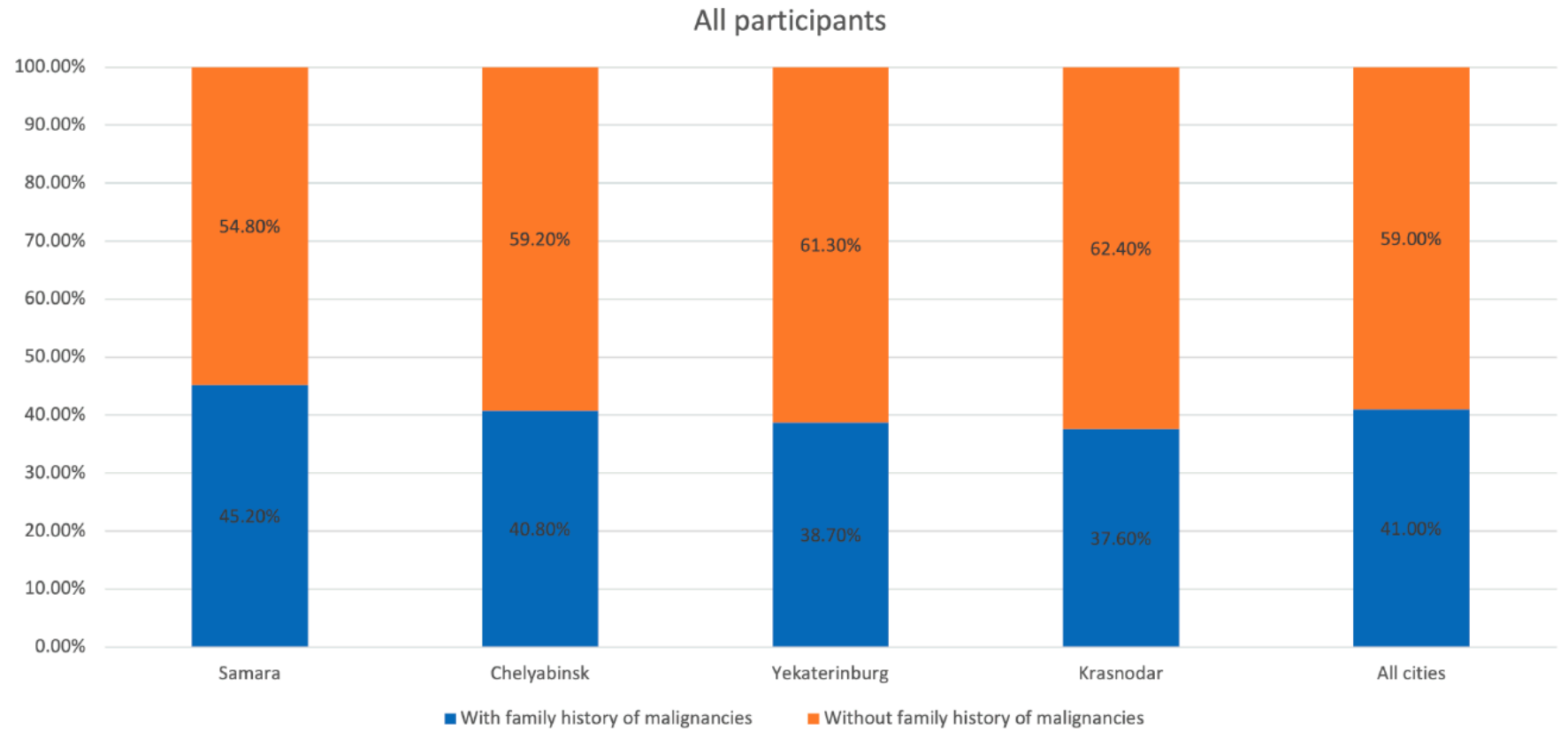

(A)

\section{Participants referred for biopsy}

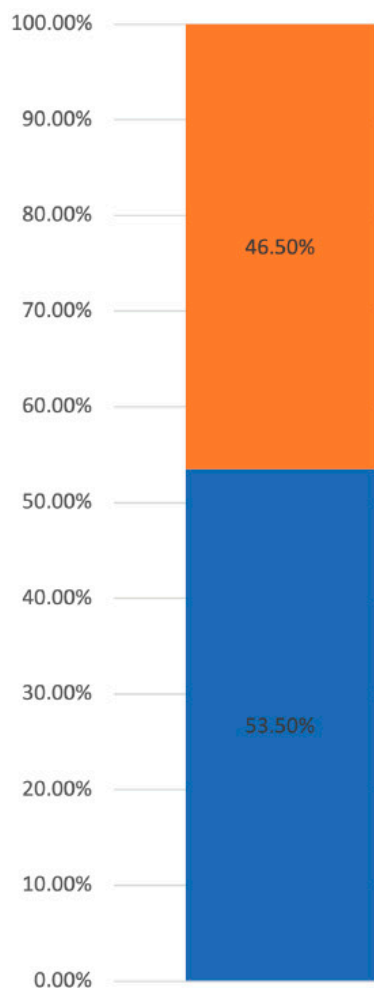

Samara

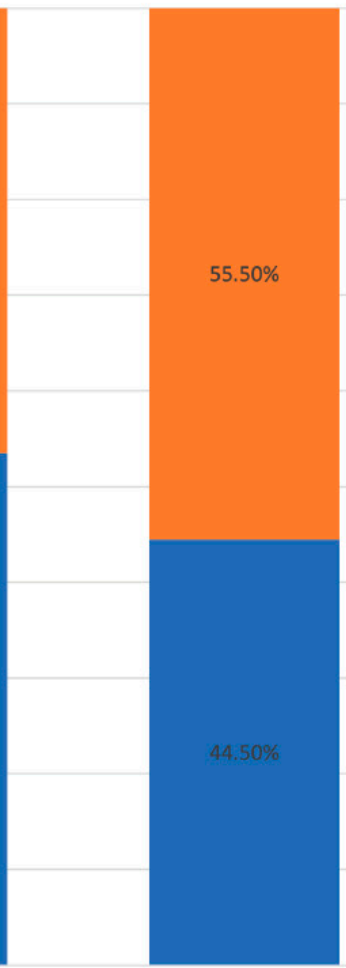

Chelyabinsk

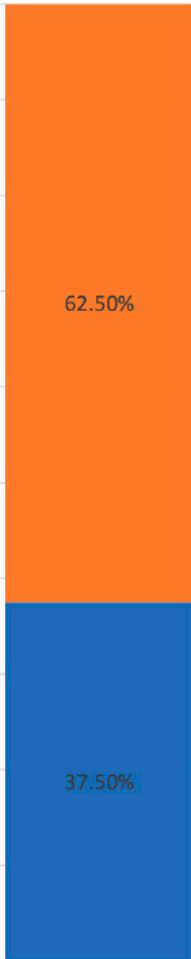

Yekaterinburg

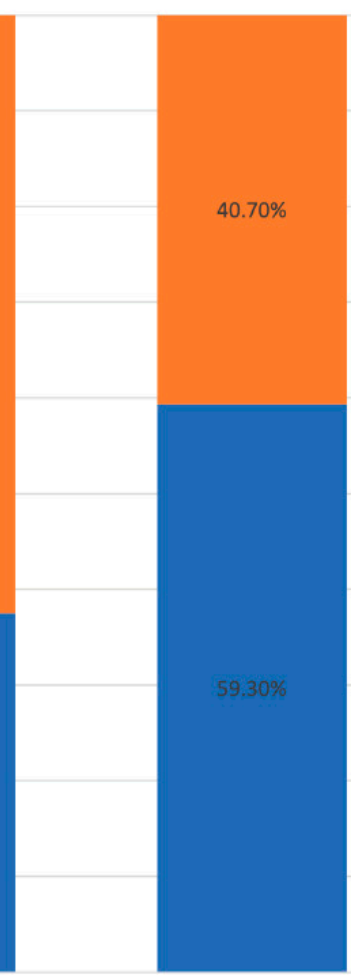

Krasnodar

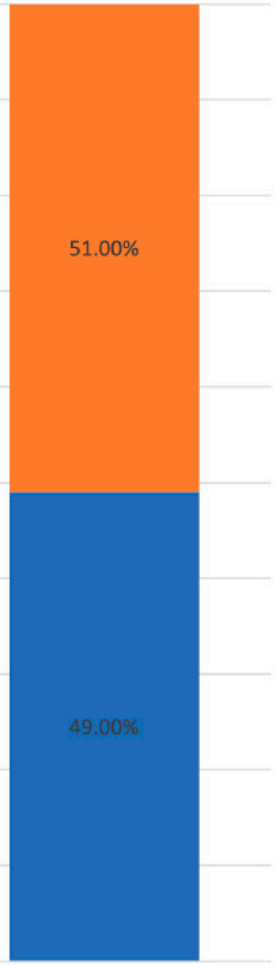

All cities

- With family history of malignancies $\quad$ Without family history of malignancies

(B)

Figure 5. Distribution of the participants by the malignancies in the family history in the studied regions. (A) All participants. (B) Participants with suspected melanoma or other skin cancers. 


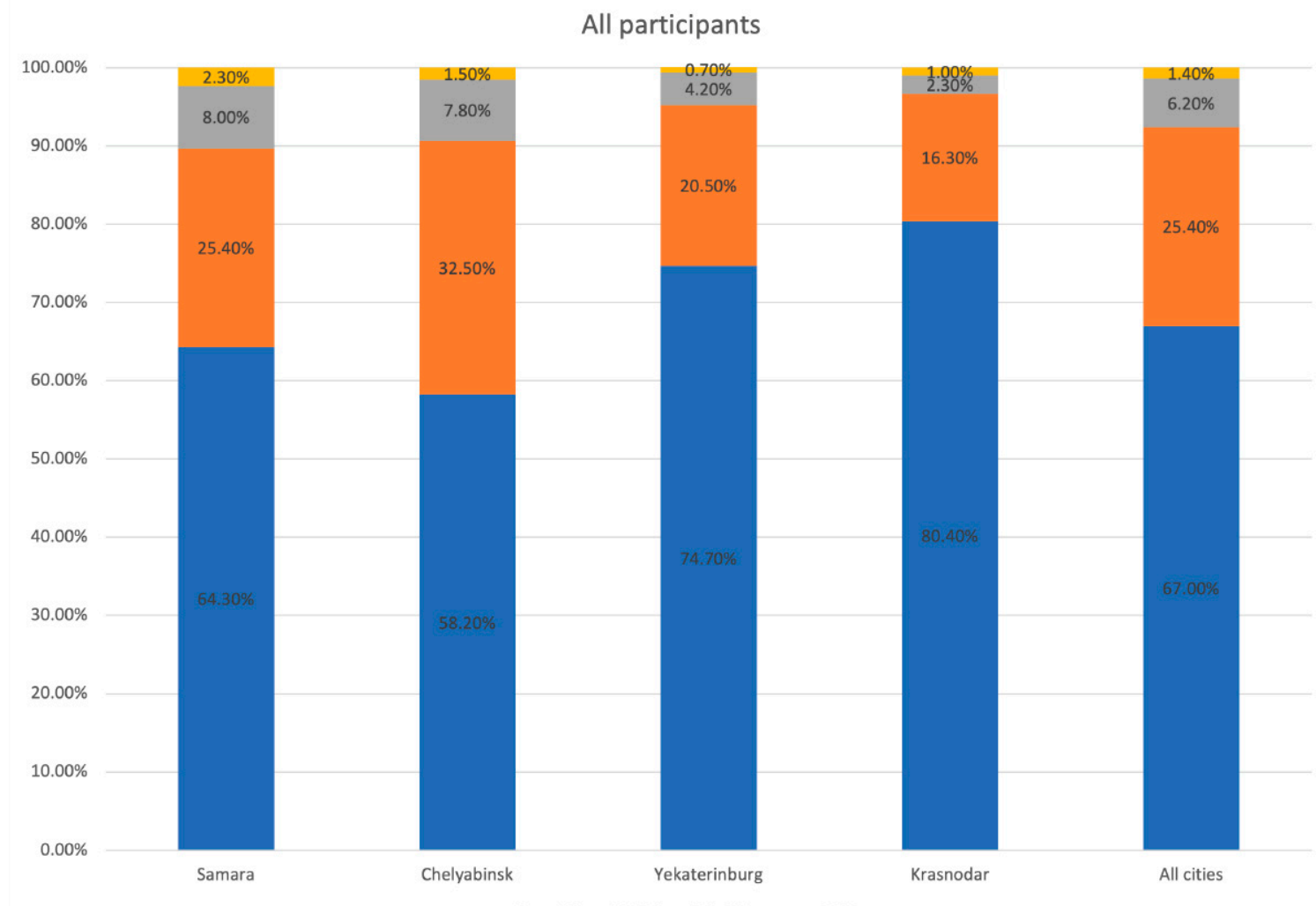

(A)

Participants referred for biopsy
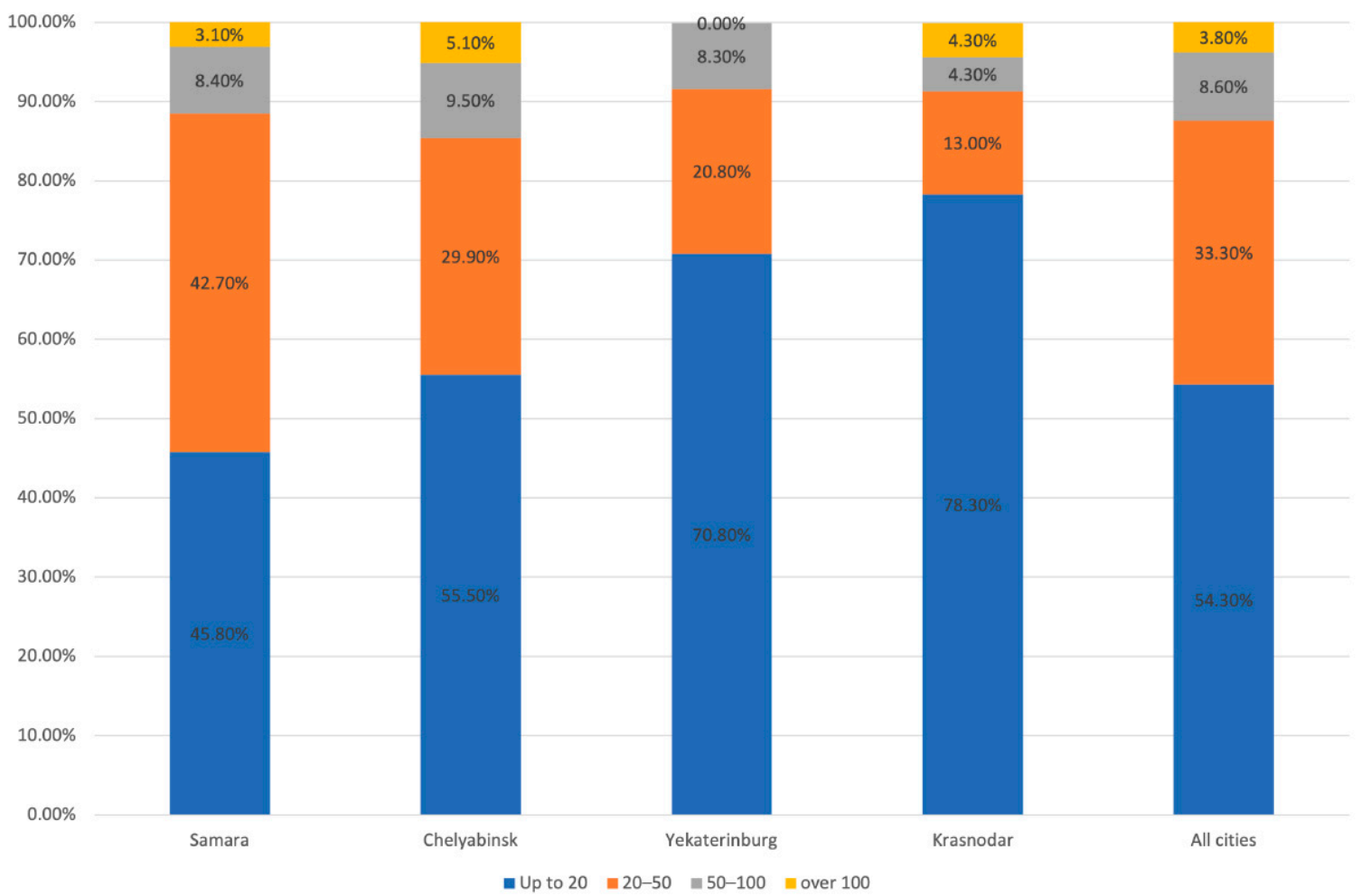

(B)

Figure 6. Distribution of the participants by the skin nevi in the studied regions. (A) All participants. (B) Participants with suspected melanoma or other skin cancers. 
The average age of the participants was 43.7 (95\% confidence interval (CI): 43.2-44.3) years. Figure 7 presents participant distribution by age and sex enrolled in the social educational LFF program.

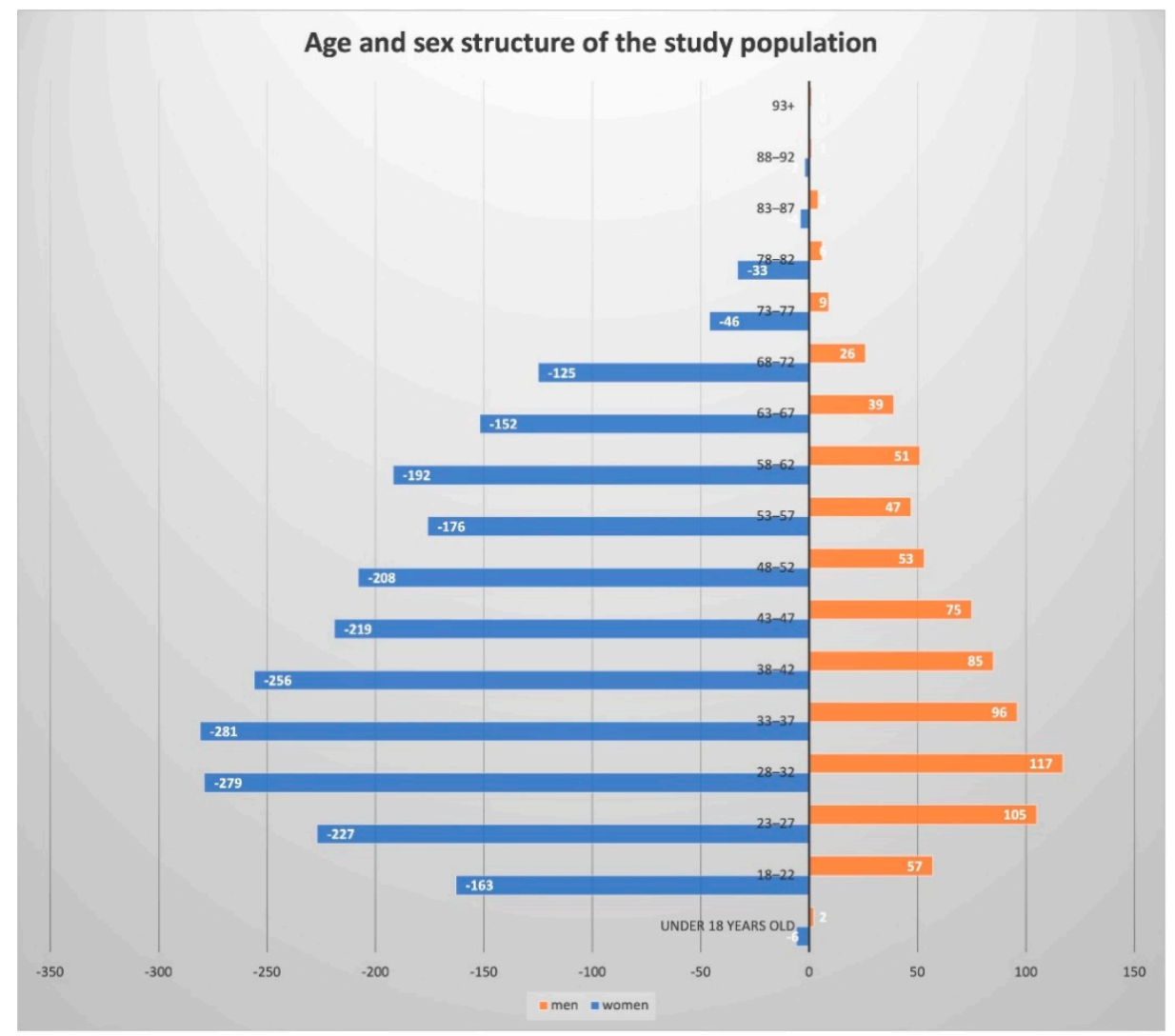

Figure 7. Distribution of the participants by age and sex.

\subsection{CM and NMSC Incidence}

3 people of 3143 participants had CM, 15-basal cell carcinoma (BCC), and 1squamous cell carcinoma in situ (SCC). CM was detected in two men (aged 40 and 72) and one woman (aged 68). The participants with confirmed melanoma had less than 20 nevi. One person had skin phototype I, 1-phototype II, and 1-phototype III. NMSC was detected in 5 men and 11 women (average age 63.6 and 69.1 years, respectively). Moreover, 11 of 16 participants (69\%) had up to 20 nevi. Almost $69 \%$ of participants with confirmed NMSC had skin phototype II, 31\% had skin phototype III, and 88\% (14 people) had a previous history of sunburn. Two of sixteen patients had concomitant cancer, one had BCC. The characteristics of participants diagnosed with melanoma or NMSC are shown in Table 2.

A total of 68 biopsy procedures were performed (including 58 excisional biopsies with pathological examination, and 10 scrapings or smears with cytological examination), see Table 3 .

Table 2. Characteristics of the participants with melanoma or non-melanoma skin cancer detected in the LFF program.

\begin{tabular}{|c|c|c|c|c|c|c|c|c|c|}
\hline City & $\operatorname{Sex}(M / F)$ & $\begin{array}{l}\text { Age (Year of } \\
\text { Birth) }\end{array}$ & $\begin{array}{c}\text { Number of } \\
\text { Nevi }\end{array}$ & $\begin{array}{c}\text { Skin Photo } \\
\text { Type }\end{array}$ & Sunburns & $\begin{array}{c}\text { Previous Cancer } \\
\text { in Personal } \\
\text { History }\end{array}$ & $\begin{array}{c}\text { Previous Cancer } \\
\text { in Family } \\
\text { History }\end{array}$ & Diagnosis & $\begin{array}{l}\text { Depth of the } \\
\text { Lesion }\end{array}$ \\
\hline Yekaterinburg & M & 72 (1947) & Up to 20 & II & No & No & No & Melanoma & Up to $1 \mathrm{~mm}$ \\
\hline Chelyabinsk & M & 40 (1979) & Up to 20 & III & Yes & No & $\begin{array}{c}\text { Yes (father, } \\
\text { gastric cancer) }\end{array}$ & Melanoma & $1 \mathrm{~mm}$ \\
\hline Samara & $\mathrm{F}$ & 68 (1951) & Up to 20 & I & Yes & No & No & Melanoma & $1 \mathrm{~mm}$ \\
\hline Krasnodar & F & 73 (1946) & Up to 20 & II & Yes & No & $\begin{array}{l}\text { Yes (father, } \\
\text { lung cancer) }\end{array}$ & $\begin{array}{c}\text { Basal cell } \\
\text { carcinoma }\end{array}$ & \\
\hline
\end{tabular}


Table 2. Cont.

\begin{tabular}{|c|c|c|c|c|c|c|c|c|c|}
\hline City & $\operatorname{Sex}(M / F)$ & $\begin{array}{c}\text { Age (Year of } \\
\text { Birth) }\end{array}$ & $\begin{array}{c}\text { Number of } \\
\text { Nevi }\end{array}$ & $\begin{array}{c}\text { Skin Photo } \\
\text { Type }\end{array}$ & Sunburns & $\begin{array}{c}\text { Previous Cancer } \\
\text { in Personal } \\
\text { History }\end{array}$ & $\begin{array}{c}\text { Previous Cancer } \\
\text { in Family } \\
\text { History }\end{array}$ & Diagnosis & $\begin{array}{l}\text { Depth of the } \\
\text { Lesion }\end{array}$ \\
\hline Krasnodar & $\mathrm{F}$ & 72 (1947) & Up to 20 & II & Yes & No & $\begin{array}{l}\text { Yes (mother, } \\
\text { skin cancer) }\end{array}$ & $\begin{array}{c}\text { Basal cell } \\
\text { carcinoma }\end{array}$ & \\
\hline Krasnodar & M & 71 (1947) & Up to 20 & II & Yes & $\begin{array}{l}\text { Yes (prostate } \\
\text { cancer) }\end{array}$ & No & $\begin{array}{l}\text { Bowen's } \\
\text { disease }\end{array}$ & \\
\hline Yekaterinburg & $\mathrm{F}$ & 68 (1951) & Up to 20 & II & Yes & No & No & $\begin{array}{c}\text { Basal cell } \\
\text { carcinoma }\end{array}$ & \\
\hline Yekaterinburg & $\mathrm{F}$ & 66 (1953) & Up to 20 & II & Yes & No & No & $\begin{array}{c}\text { Basal cell } \\
\text { carcinoma }\end{array}$ & \\
\hline Yekaterinburg & M & 68 (1951) & Up to 20 & III & Yes & No & $\begin{array}{l}\text { Yes (father, } \\
\text { mother) }\end{array}$ & $\begin{array}{c}\text { Basal cell } \\
\text { carcinoma }\end{array}$ & \\
\hline Yekaterinburg & $\mathrm{F}$ & 81 (1938) & Up to 20 & II & Yes & No & $\begin{array}{c}\text { Yes (mother, } \\
\text { uterine cancer) }\end{array}$ & $\begin{array}{c}\text { Basal cell } \\
\text { carcinoma }\end{array}$ & \\
\hline Yekaterinburg & $\mathrm{F}$ & 83 (1936) & Up to 20 & II & Yes & No & $\begin{array}{l}\text { Yes (mother: lung } \\
\text { cancer, sister: } \\
\text { ovarian cancer) }\end{array}$ & $\begin{array}{l}\text { Basal cell } \\
\text { carcinoma }\end{array}$ & \\
\hline Yekaterinburg & $\mathrm{F}$ & 56 (1963) & $20-50$ & II & Yes & No & Yes (mother) & $\begin{array}{c}\text { Basal cell } \\
\text { carcinoma }\end{array}$ & \\
\hline Chelyabinsk & M & 51 (1968) & 50-100 & III & Yes & No & $\begin{array}{l}\text { Yes (father, } \\
\text { gastric cancer) }\end{array}$ & $\begin{array}{l}\text { Basal cell } \\
\text { carcinoma }\end{array}$ & \\
\hline Chelyabinsk & M & 48 (1970) & $50-100$ & II & Yes & No & Yes & $\begin{array}{c}\text { Basal cell } \\
\text { carcinoma }\end{array}$ & \\
\hline Chelyabinsk & M & 80 (1939) & Up to 20 & II & No & No & No & $\begin{array}{c}\text { Basal cell } \\
\text { carcinoma }\end{array}$ & \\
\hline Chelyabinsk & $\mathrm{F}$ & 71 (1948) & Up to 20 & III & Yes & No & No & $\begin{array}{c}\text { Basal cell } \\
\text { carcinoma }\end{array}$ & \\
\hline Samara & $\mathrm{F}$ & 70 (1949) & Up to 20 & III & No & No & No & $\begin{array}{c}\text { Basal cell } \\
\text { carcinoma }\end{array}$ & \\
\hline Samara & $\mathrm{F}$ & 61 (1958) & Over 100 & III & Yes & No & No & $\begin{array}{l}\text { Basal cell } \\
\text { carcinoma }\end{array}$ & \\
\hline Samara & $\mathrm{F}$ & $59(1960)$ & $20-50$ & II & Yes & $\begin{array}{l}\text { Yes (basal cell } \\
\text { carcinoma) }\end{array}$ & No data & $\begin{array}{c}\text { Basal cell } \\
\text { carcinoma }\end{array}$ & \\
\hline
\end{tabular}

Table 3. Skin lesion biopsies performed after skin examinations of the LFF program participants.

\begin{tabular}{|c|c|c|c|c|}
\hline \multicolumn{5}{|c|}{ Biopsy Results } \\
\hline & & Absolute Number & $\begin{array}{c}\text { Percentage of All } \\
\text { Participants }(n=3143)\end{array}$ & $\begin{array}{l}\text { Percentage of Participants } \\
\text { Who were Referred for } \\
\text { Biopsy/Underwent Biopsy } \\
\text { without Referral }(n=100)^{1}\end{array}$ \\
\hline \multirow{13}{*}{$\begin{array}{l}\text { Participants } \\
\text { referred for biopsy: }\end{array}$} & Non-informative & 11 & 0.3 & 11.0 \\
\hline & Melanocytic nevus & 23 & 0.7 & 23.0 \\
\hline & Other benign skin lesions & 3 & 0.1 & 3.0 \\
\hline & Hemangioma & 1 & 0.0 & 1.0 \\
\hline & Seborrheic keratosis & 5 & 0.2 & 5.0 \\
\hline & Inflammatory skin diseases & 3 & 0.1 & 3.0 \\
\hline & Sebaceous hyperplasia & 2 & 0.1 & 2.0 \\
\hline & Ulcer & 1 & 0.0 & 1.0 \\
\hline & Skin melanoma & 3 & 0.1 & 3.0 \\
\hline & Skin cancer & 16 & 0.5 & 16.0 \\
\hline & Did not have biopsy performed & 5 & 0.2 & 5.0 \\
\hline & $\begin{array}{l}\text { Did not attend a biopsy } \\
\text { appointment }\end{array}$ & 27 & 0.9 & 27.0 \\
\hline & Total & 100 & 3.2 & 100.0 \\
\hline $\begin{array}{l}\text { Participants } \\
\text { not referred for } \\
\text { biopsy: }\end{array}$ & & 3043 & 96.8 & \\
\hline Total & & 3143 & 100.0 & \\
\hline
\end{tabular}

${ }^{1}$ Seven participants underwent biopsy in Samara, including 3 persons who received referral "Healthy. No further consultation required" after examination by the oncologist; 3 who received referral "Healthy, with a high risk of skin cancer, benign lesions. Follow up by a dermatologist recommended" after examination by the oncologist; and 1 who did not attend the second-stage examination by the oncologist or had no data available at the second-stage examination by the oncologist. 
Three (100\%) patients with CM had Breslow's depth of $1 \mathrm{~mm}$ (which corresponds to stage $\mathrm{T} 1 \mathrm{~b}$ and stage I).

\section{Discussion}

Although screening high-risk patients for melanoma has been a hot issue over the decades, no randomized controlled trials have been presented and therefore, we cannot evaluate the effect of screening on disease-related mortality.

The most extensive studies demonstrated controversial results of CM screening [7-16].

A two-stage program on melanoma and non-melanoma skin cancer (SCREEN) was introduced in Schleswig-Holstein, Germany, in 2003. Approximately 19\% of the regional population participated in the program. The results showed an increase in invasive melanoma incidence by $34 \%$ among the SCREEN participants. Five years after the program completion, the researchers registered a significant reduction of the melanoma-related mortality. The authors of the program admitted they could not arrange a randomized controlled trial [17]. The SCREEN results boosted a skin cancer screening program across Germany, however no decrease in melanoma-related mortality was registered at the federal level [18].

A large melanoma screening program (1984-1996) involved the employees of the Lawrence Livermore National Laboratory in the United States. Any participant who detected a suspicious lesion during skin self-examination went for specialist's medical examination. Participants with melanoma, as well as individuals of the high-risk group, underwent planned examinations every 3-24 months. The study showed a reduction in the rough incidence rate of melanoma with a depth of $>0.75 \mathrm{~mm}$ (22.1-4.62 cases per 100,000 for the study period and 15.13-4.62 cases per 100,000 during the screening period). Though the estimated expected mortality rate was 3.39 , no melanoma-related deaths occurred over the observation period. The authors declared some correlation between the decrease in melanoma-related mortality and decrease in the incidence of mature melanoma (depth > $0.75 \mathrm{~mm}$ ), the increase in the awareness of the studied population, the introduction of skin self-examination, and screening examinations for people at high risk. However, that study was neither randomized, nor controlled [19].

Finally, a large randomized study of melanoma screening started in Australia. Phase I lasted 18 months and involved 18 community-based populations (the study arm -9 communities, and the control arm-9). The number of participants in the screening study arm was higher than that of the control arm; however, the study was discontinued due to funding problems [20].

In addition, numerous reports describe social educational projects, such as Euromelanoma Day [21]. The present LFF program seems very much similar to the latter in terms of its organization.

The results of the LFF program showed that the studied population had low awareness of CM and NMSC and their risk factors. Although the program included information and awareness-raising campaign, the study did not evaluate the follow up effect of the distributed educational materials. However, a 2-week information campaign involving various media tools ensured a large number of people participated in the program (3134 enrolled participants, with initially planned 3200).

As a result of active screening (i.e., invitation for skin examinations), the researchers could pool the patients and improve CM detection that reached 3 cases of 3143 participants. The result corresponds to the incidence of 95.45 per 100,000 people, while an average Russian rough incidence rate is 7.76 cases per 100,000 adult population; thus, the study results showed 12.3 times higher incidence than the average incidence rate in Russia. NMSC incidence data showed similar result.

Apparently, given such a small number of participants, the program could not ensure any essential effect on CM or NMSC-related mortality in the participating regions.

The age characteristics of the program participants under screening for melanoma differed significantly from the average age of CM patients at the time of diagnosis; in Russia, the average age of the first detected CM is 61.7 years [1]. The Russian population 
with first detected NMSC is even older: the average age of patients with NMSC is 69.7 at the time of diagnosis [1].

We believe that the younger age of examined program participants might have some impact on the CM and NMSC detection results. The CM detection rate in the studied population reached $0.10 \%$ (3 patients of 3143 participants), and the detection rate of NMSCs (BCC and SCC) accounted for $0.51 \%$ (16 patients out of 3143 participants).

We compared CM incidence registered in LFF program with the incidence in the Euromelanoma Day in Sweden, 2008 [21]. A total of 24 patients of 2799 examined in Sweden had histologically confirmed CMs; therefore, the detection rate accounted for $0.9 \%$ [14]. The available data of the Euromelanoma Day project introduced in 2009-2010 in 20 European countries showed that Sweden had the highest melanoma detection rate among the countries included in the analysis [15].

Several factors may contribute to the lower CM detection rate in the LFF program. Firstly, the CM incidence in Sweden is significantly higher than that in Russia. The standardized incidence rates in Sweden were 23.5 in men and 26.2 in women per 100,000 in 2018 [22]; while in Russia, the standardized incidence rates were 4.57 in men and 4.97 in women [1].

Secondly, the average age of participants in the Swedish Euromelanoma Day was higher than that in the Russian LFF Program (53 and 43.7 years, respectively). During the Euromelanoma Day in Sweden, patients were charged for their visits, which could prevent people with no suspicion for skin cancers from participation in the project. The participants of Euromelanoma Day who had suspicious lesions underwent excision surgery on the examination day, which reduced the risk of missing histological confirmation of the diagnosis as a result of the participant's non-appearance for the biopsy after examination. Thus, some participants of the LFF program with suspected melanoma or non-melanoma skin cancer, who had to undergo a biopsy, did not turn up for that appointment ( 25 people).

To increase the program effectiveness, the awareness-raising campaign should focus on the people at high risk (older people with sun-damaged skin) and therefore, the authors should analyze and adapt the information campaign.

We consider it important to pursue certain organizing measures to avoid "losses" during the inter-stage routing of the participants (initial examination-biopsy). One such measure is performing biopsy on the day of the examination.

In addition, the proficiency of dermatologists, oncologists, and pathologists in detecting skin malignancies remains one of the key factors. Possible misdiagnosis, such as incorrect phototypes or underestimated number of nevi, etc., should be minimized.

The improvement of these factors combined with administrative support can ensure the start of a CM screening program in different regions of the country.

\section{Conclusions}

The participants showed high interest in early skin cancer detection program. However, the study revealed that a high percentage of LFF program participants had an incorrect understanding of melanoma and skin cancer, their risk factors, and treatment methods.

The detectability of melanoma and non-melanoma skin cancers is comparable to that of skin cancers obtained in similar screening projects. The early stage disease was confirmed for the detected melanoma and skin cancer. The incidence rate of CM and NMSCs among the program participants was higher than in general public.

The results suggest that social educational programs should be continued and target high-risk population. The implementation of the program also demonstrated what should be improved in the campaign, and it revealed the need for high-qualified medical personnel. Firstly, the design and organizational efforts should focus on the higher risk groups to reach senior members of the society. Additionally, it appeared important to improve the patient routing to avoid discrepancies between the examination stage and biopsy completion so that, if necessary, biopsy could be performed on the examination day. Furthermore, the electronic system of collecting the examination results should be upgraded. Finally, 
the involved specialists, such as dermatologists, oncologists, and pathologists should have appropriate qualification and motivation to participate in such programs.

Further well-organized controlled studies are required to evaluate if $\mathrm{CM}$ screening could decrease melanoma mortality rate.

Author Contributions: Conceptualization, L.D., I.S. (Igor Samoylenko), I.U., and I.S. (Igor Sinelnikov); data curation, N.V. and I.S. (Igor Samoylenko); writing-original draft preparation, N.V. and I.S. (Igor Samoylenko), writing-review and editing, I.S. (Igor Samoylenko), I.U., I.S. (Irina Shubina) and I.S. (Igor Sinelnikov); project administration, L.D. All authors have read and agreed to the published version of the manuscript.

Funding: The social educational program "Life Fear-Free" received financial and organizational support from BIOCAD (Russian innovative biotech company).

Institutional Review Board Statement: The study was conducted in accordance with the Declaration of Helsinki, and the program was approved by the Ethics Committee of the Federal State Budgetary Institution "N.N. Blokhin National Medical Research Center of Oncology" of the Ministry of Health of Russia (Program approval of 5.08. 2019).

Informed Consent Statement: Informed consent was obtained from all participants involved in the study.

Conflicts of Interest: The authors declare no conflict of interest.

\section{References}

1. Kaprin, A.; Starinsky, V.; Shakhzadova, O. Status of Oncological Healthcare for the Population of Russia in 2019; P.A. Herzen Moscow Oncology Research Center affiliated to FSBI NMRRC of the Ministry of Health of Russia: Moscow, Russia, 2020; 239p.

2. Van Akkooi, A.C.; de Wilt, J.H.; Verhoef, C.; Schmitz, P.I.; van Geel, A.N.; Eggermont, A.M.; Kliffen, M. Clinical relevance of melanoma micrometastases $(<0.1 \mathrm{~mm})$ in sentinel nodes: Are these nodes to be considered negative? Ann. Oncol. 2006, 17, $1578-1585$. [CrossRef] [PubMed]

3. Samoylenko, I.; Kharkevich, G.; Utyashev, I.A.; Vishnevskaya, Y.V.; Orlova, K.V.; Demidov, L.V. Do we have early detection of cutaneous melanoma in Russia? Single-institution observational study. J. Clin. Oncol. 2014, 32 (Suppl. 15), e20027.

4. Elmore, J.G.; Barnhill, R.L.; Elder, D.E.; Longton, G.M.; Pepe, M.S.; Reisch, L.M.; Carney, P.A.; Titus, L.J.; Nelson, H.D.; Onega, T. Pathologists' diagnosis of invasive melanoma and melanocytic proliferations: Observer accuracy and reproducibility study. BMJ 2017, 28, 357. [CrossRef] [PubMed]

5. Analytical Report on the Level of Awareness of Russians about Melanoma and Willingness to Monitor the Condition of Their moles on Their Own or by a Doctor. 2019. Available online: https:/ / wciom.ru/index.php?id=236\&uid=9941 (accessed on 5 June 2020).

6. Open Information and Educational Materials on the Prevention and Diagnosis of Cancer. 2019. Available online: https: / / xn--80aabdqdkeb7fkm5b.xn--p1ai (accessed on 5 June 2020).

7. Krol, S.; Keijser, L.M.; van der Rhee, H.J.; Welvaart, K. Screening for skin cancer in The Netherlands. Acta Derm Venereol. 1991, 71,317-321. [PubMed]

8. Berwick, M.; Begg, C.B.; Fine, J.A.; Roush, G.C.; Barnhill, R.L. Screening for cutaneous melanoma by skin self-examination. J. Natl. Cancer Inst. 1996, 88, 17-23. [CrossRef] [PubMed]

9. McPherson, M.; Elwood, M.; English, D.R.; Baade, P.D.; Youl, P.H.; Aitken, J.F. Presentation and detection of invasive melanoma in a high-risk population. J. Am. Acad. Dermatol. 2006, 54, 783-792. [CrossRef] [PubMed]

10. Paoli, J.; Danielsson, M.; Wennberg, A.M. Results of the 'Euromelanoma Day' screening campaign in Sweden 2008. J. Eur. Acad. Dermatol. Venereol. 2009, 23, 1304-1310. [CrossRef] [PubMed]

11. Seidenari, S.; Benati, E.; Ponti, G.; Borsari, S.; Ferrari, C.; Albertini, G.; Arcangeli, F.; Aste, N.; Bernengo, M.G.; Bongiorno, M.R. Italian Euromelanoma Day Screening Campaign (2005-2007) and the planning of melanoma screening strategies. Eur J. Cancer Prev. 2012, 21, 89-95. [CrossRef] [PubMed]

12. Cristofolini, M.; Boi, S.; Cattoni, D.; Sicher, M.C.; Decarli, A.; Micciolo, R. A 10-Year Follow-Up Study of Subjects Recruited in a Health Campaign for the Early Diagnosis of Cutaneous Melanoma: Suggestions for the Screening Timetable. Dermatology 2015, 231, 345-352. [CrossRef] [PubMed]

13. Wernli, K.J.; Henrikson, N.B.; Morrison, C.C.; Nguyen, M.; Pocobelli, G.; Whitlock, E.P. Screening for Skin Cancer in Adults: An. Updated Systematic Evidence Review for the US Preventive Services Task Force; U.S. Preventive Services Task Force Evidence Syntheses, formerly Systematic Evidence Reviews: Rockville, MD, USA, 2016.

14. Ferris, L.K.; Saul, M.I.; Lin, Y.; Ding, F.; Weinstock, M.A.; Geller, A.C.; Yuan, J.M.; Neuren, E.; Maddukuri, S.; Solano, F.X.; et al. A Large Skin Cancer Screening Quality Initiative: Description and First-Year Outcomes. JAMA Oncol. 2017, 3, $1112-1115$. [CrossRef] [PubMed] 
15. Hubner, J.; Waldmann, A.; Eisemann, N.; Noftz, M.; Geller, A.C.; Weinstock, M.A.; Volkmer, B.; Greinert, R.; Breitbart, E.W.; Katalinic, A. Association between risk factors and detection of cutaneous melanoma in the setting of a population-based skin cancer screening. Eur. J. Cancer Prev. 2018, 27, 563-569. [CrossRef] [PubMed]

16. Palkina, N.; Sergeeva, O.; Ruksha, T.; Artyukhov, I. Melanoma Screening Day in Krasnoyarsk Krai of the Russian Federation: Results from 2015-2016. Asian Pac. J. Cancer Prev. 2018, 19, 503-507. [PubMed]

17. Breitbart, E.W.; Waldmann, A.; Nolte, S.; Capellaro, M.; Greinert, R.; Volkmer, B.; Katalinic, A. Systematic skin cancer screening in Northern Germany. J. Am. Acad. Dermatol. 2012, 66, 201-211. [CrossRef] [PubMed]

18. Stang, A.; Jockel, K.H. Does skin cancer screening save lives? A detailed analysis of mortality time trends in Schleswig-Holstein and Germany. Cancer 2016, 122, 432-437. [CrossRef] [PubMed]

19. Schneider, J.S.; Moore, D.H.; Mendelsohn, M.L. Screening program reduced melanoma mortality at the Lawrence Livermore National Laboratory, 1984 to 1996. J. Am. Acad. Dermatol. 2008, 58, 741-749. [CrossRef] [PubMed]

20. Aitken, J.F.; Elwood, J.M.; Lowe, J.B.; Firman, D.W.; Balanda, K.P.; Ring, I.T. A randomized trial of population screening for melanoma. J. Med. Screen. 2002, 9, 33-37. [CrossRef] [PubMed]

21. Van der Leest, R.J.; de Vries, E.; Bulliard, J.L.; Paoli, J.; Peris, K.; Stratigos, A.J.; Trakatelli, M.; Maselis, T.J.E.M.L.; Šitum, M.; Pallouras, A.C.; et al. The Euromelanoma skin cancer prevention campaign in Europe: Characteristics and results of 2009 and 2010. J. Eur. Acad. Dermatol. Venereol. 2011, 25, 1455-1465. [CrossRef] [PubMed]

22. Bray, F.; Ferlay, J.; Soerjomataram, I.; Siegel, R.L.; Torre, L.A.; Jemal, A. Global cancer statistics 2018: GLOBOCAN estimates of incidence and mortality worldwide for 36 cancers in 185 countries. CA Cancer J. Clin. 2018, 68, 394-424. [CrossRef] [PubMed] 